\title{
Impacts of wind power development on Oklahoma's public schools
}

\author{
Becca Castleberry ${ }^{1}$ and J. Scott Greene ${ }^{2^{*}}$
}

\begin{abstract}
Background: The development of wind energy in western Oklahoma has expanded dramatically in recent years, as the amount of installed capacity has gone from 0 in 2002 to enough turbines to generate approximately 20\% of Oklahoma's electrical needs in 2016. Associated with that development has been an increase in tax revenue and support for local schools, including many in struggling areas. This paper examines and quantifies the overall impact of the increased wind-industry related tax revenue in western Oklahoma.

Methods: Variables collected and analyzed for this study include: percentage of revenue from local and county sources, student-teacher ratios, and per-student expenditures. This information was obtained for each school district from 1997 to 2015. The data then mapped and analyzed using both statistical and inferential analysis. T tests and Mann Whitney $U$ tests were utilized identify statistically meaningful differences between school districts with and without wind turbines. In addition, a longitudinal temporal analysis was undertaken for selected locations to further illustrate the impact of the wind farms on the region.

Results: The spatial patterns of local school revenue and related variables have been analyzed and compared to available socioeconomic and demographic information. Spatial and multivariate analysis has been undertaken to highlight differences in characteristics of public school districts with and without wind turbines. Results show significant differences in revenue from local and county sources between school districts with and without wind farms. However, school districts with wind farms did not have higher per-student expenditures or lower student-teacher ratios than surrounding districts. The significant change in percentage of revenue from local and county sources illustrates the relative importance of the industry, especially during challenging economic times and particularly in those areas with fewer other revenue sources.
\end{abstract}

Conclusions: Though school districts with wind farms did not differ from surrounding districts in terms of per-student expenditures or student-teacher ratios, the significant difference in revenue from local and county sources suggests these districts may be less susceptible to changes in funding from state and federal sources.

Keywords: Wind power, Oklahoma, Schools

\section{Background}

Although the wind industry has stimulated Oklahoma's economy over the last 15 years, there are examples which illustrate how the development's impact on the community depends on the community's ability to offer the necessary goods and services required for the development of a wind farm [1]. Additionally, the American Wind Energy Association shows that all of the manufacturing facilities for wind power development are in

\footnotetext{
* Correspondence: jgreene@ou.edu

${ }^{2}$ Department of Geography and Environmental Sustainability, University of

Oklahoma, 100 E. Boyd St, Suite 510, Norman, OK 73019, USA

Full list of author information is available at the end of the article
}

central or eastern Oklahoma while the actual wind farms are predominantly in western Oklahoma [2]. This suggests the communities with wind farms may not realize all of the economic benefits associated with wind power development but that these benefits are dispersed across the state. However, there are other ways in which the local communities can benefit.

The existing scientific literature shows the potential community-level economic impacts of the wind industry, including job creation, the effects of job creation on local economies, increased property tax base, and its potential impacts on local services such as schools, fire 
and rescue, and infrastructure. Perhaps, the most widely discussed economic aspect of wind power development is that of job creation. Throughout the development of a wind project, jobs are created predominantly during the construction phase, with some jobs remaining for the operation and maintenance phase. According to the US Department of Energy, 50,500 people in the USA were directly employed by the wind industry in the form of manufacturing, equipment supply, construction, or operation and maintenance jobs as of 2013 [3]. Since that time, the wind industry has seen sustained growth, so those numbers are clearly much higher today.

Other authors have examined job creation at more specific locations within the USA. For example, Brown et al. [4] identified an increase on 0.5 jobs per MW of an installed capacity for a study period of 2000-2008 within the Great Plains. Slattery et al. [5] estimated a total of 4100 full-time equivalent jobs would be created as a result of the installation of $1398 \mathrm{MW}$ of wind power in Texas. Other authors have analyzed case studies to estimate the total job creation as a result of individual wind projects. For example, Greene and Geisken [1] estimate a total of 148 jobs were created during the construction phase as a result of the installation of a 147 MW facility in western Oklahoma. Similarly, it has been estimated that that 185 jobs were created during the construction of a $390 \mathrm{MW}$ wind farm in Washington State, with 85 jobs to be created for the operation and maintenance phase of this facility [6]. A similar study shows that 269 jobs were created during construction, and 10 jobs during the operation and maintenance phase for a $159 \mathrm{MW}$ facility in North Dakota [7]. Related to job creation, a recent study identified a 1.5 million euro impact to communities in northern Scotland as a result of construction and operation and maintenance jobs in the wind industry [8].

Notice that these numbers can be quite different from another (e.g., 85 jobs for 390 MW facility and 10 jobs for a 159-MW farm) for these last two studies. Similarly, for the studies mentioned above, the job creation values are also dramatically different from one another (e.g., 2.9 jobs/MW for one study and 0.5 jobs/MW for the other), so one is tempted to discount the relative impact of job creation of wind farms. This suggests a number of points. First, it illustrates that although there are obviously some number of jobs created during all phases of wind farm development and operations, the nature of the jobs is dependent upon many factors, such as the size of the turbines, the location and terrain, and the nature of the electrical grid. Second, it suggests that since the model estimates are quite different from one another, the results of the modeled studies should be used as a guide to the approximate relative magnitude of the job creation impact rather than the actual numbers themselves. It is the opinion of the authors here that given the improved technology in the industry, and the increase in the size of the turbines, which results in more energy produced from each turbine, the lower estimates of the job creation numbers are far more likely to be closer to the true values. Finally, it also argues for examinations of other ways in which the wind turbines may have impacts on the local community and thus serve as one driver for the study presented here.

In addition to job creation as a result of wind power development, communities may realize other economic benefits such as increased tax revenues. Increased tax revenues from a wind project can be used by local governments to improve infrastructure or to purchase goods and services [9]. The US Government Accountability Office explains how increased tax revenue can be in the form of sales tax from an increase in spending at local businesses from those employed in the wind industry during the construction phase of a particular project [10]. More specifically, in a case study of a community in western Oklahoma, results show that the installation of a $147 \mathrm{MW}$ wind farm contributed to an increase of $\$ 27$ million in local spending [1]. Wind power development in a community can also potentially increase tax revenues from income taxes generated from those employed in the wind industry [10]. Additionally, several studies have identified that property tax revenues as a result of wind power development can provide additional revenue to be used by local services such as schools, hospitals, fire departments, and other services [10-12].

Similarly, two addition reports [12, 13] identify economic benefits that local communities may experience as a result of wind power development. These impacts include employment, increases in income, tax revenues, and payments to landowners with wind turbines on their property. Both of these studies discuss how additional tax revenue can be used to support local schools, hospitals, the fire department, or local infrastructure $[12,13]$. Wind power development may have a more significant impact on rural economies, particularly those where farming is the only major industry [13].

A number of studies have quantified the economic benefits such as lease payments or increased tax revenue that communities with recent wind power development have experienced. For example, it is estimated that landowners in the state of Texas can collectively receive $\$ 5$ million annually in lease payments [14]. At the community level, lease payments can range from about $\$ 400,000$ in Oklahoma to $\$ 413,000$ in North Dakota in a given year $[1,7]$.

Along with lease payments, increased tax revenues can significantly benefit services within local communities. The US GAO identifies property tax revenues as a result of wind turbines can range between $\$ 470,000$ and $\$ 660,000$ in a given year in Minnesota 
[10]. Furthermore, the US GAO discussed school districts in Pecos County, Texas, received approximately $\$ 5$ million in a given year as a result of property tax revenues that accompanied recent wind power development [10]. Several other studies have produced similar findings. For example, in a study on the economic effects of wind power in North Dakota estimated that the expected property tax revenues associated with the project to be $\$ 456,000$ per year [7]. Furthermore, in Washington State, tax revenues from the proposed wind farm available to local services are estimated to be $\$ 693,000$ per year [6]. While in a study of a community in western Oklahoma, the increase in property tax revenue is estimated to be over $\$ 600,000$ per year [1].

Although a number of authors have quantified the economic benefits of wind power development at the community level in the form of jobs created, increased spending at local businesses, lease payments to property owners, and increased revenue from property taxes, little research has been done to more closely examine how exactly local services, schools in particular, have been impacted by industrial-scale wind development within their communities. Furthermore, little research has examined how communities with industrial-scale wind power differ socioeconomically from surrounding communities with no such development, although there has been some research undertaken on this. In a study of nine counties (six with wind farms and three without wind farms) in west Texas, the quality of life, demographics, school quality, and property tax rates was analyzed [15]. Assuming quality of life was related to education, the study concluded that educated residents had not been avoiding areas with wind turbines, suggesting the turbines had not affected quality of life [15]. Additionally, this study identified decreased pollution when compared to electricity generation from fossil fuels as another contributing factor to quality of life in communities with wind farms [15].

Variables that were examined related to public school quality consisted of per pupil expenditures, studentteacher ratios, and test performance [15]. Data were collected for the 2008-2009 and 2010-2011 calendar year. The results of this analysis show that schools in counties with wind farms have experienced significant increases in per pupil spending by $\$ 1239$ per year and decreases in student-teacher ratios by 1.98 . However, it is unclear that the degree to which Texas schools within counties with wind farms were affected as a result of property tax revenues, as Texas reallocates property tax revenues from rich to poor districts in the state [15]. Thus, approximately $60 \%$ of the new revenue from previously poor districts (those with recent wind power development) had been redistributed to districts across the state.
Similar to the previous study, another effort examined the community-level impacts of wind power development at the county level in Texas [16]. A total of 222 counties were analyzed consisting of 31 with industrialscale wind power and 191 without wind power. Variables analyzed included employment, personal income, property taxes, and public school expenditures. This effort found modest employment benefits in the form of direct and indirect employment associated with wind power development, but that per capita income increased significantly [16]. Furthermore, the authors found counties and schools benefited from increased property taxes. However, while districts with wind power development have experienced changes in the property tax base, the relationship between increased tax base and per pupil spending is most likely less pronounced due to the school funding structure discussed previously whereby local funds are distributed across the state from richer to poorer districts $[15,16]$.

To date, these efforts have most closely examined the impacts of utility-scale wind power development on local communities, public schools in particular $[15,16]$. This shows that in-depth analysis on how wind power development affects schools has been done in only a limited number of cases and not for Oklahoma. While these studies have examined the impacts of wind power development on Texas counties (and the implications for public schools); however, the funding structure for schools in Texas differs somewhat from that of Oklahoma. Thus, the effects upon schools of wind power development in Texas may differ from those in Oklahoma. Furthermore, the funding structure in Oklahoma is examined in order to provide additional context for the ways in which Oklahoma's public schools may be affected by wind power development.

Given that wind power development can affect local property tax revenues as has been shown by the research described briefly above, it is useful to provide an overview of the funding structure of public schools in Oklahoma in order to understand how the changes in property tax revenue from wind turbines could potentially affect a particular school district. Public schools in Oklahoma received $47.7 \%$ of funding from the state, $11.6 \%$ from the federal government, and $40.8 \%$ from local and county sources, totaling approximately $\$ 5.9$ billion for the 2014-2015 school year [17]. Additionally, a typical school district in Oklahoma receives approximately $30 \%$ of its funding from property taxes [17]. School districts that receive a larger percentage of revenue from local and county sources are typically better off economically while those that receive a smaller percentage of revenue from local and county sources are worse off economically. Percentage of revenue from local and county sources varies from 67\% in Grant 
County to $14.4 \%$ in Adair County. However, school districts that are able to raise money from local and county revenues will not receive as much funding from the state, as state funding is allocated to districts that do not have the ability to raise money through local and county revenues [17].

Although it has been shown that wind power development can increase the local property tax base, state-level policies regarding ad valorem taxes for renewable energy projects differ across the USA. Some states have adopted Payment in Lieu of Taxes (PILOT) programs in order to defer the increase of property taxes [18]. A recent effort provides an overview of different state-level policies on the taxation of renewable energy development on personal property. For example, the state of Wisconsin exempts renewables from ad valorem taxation while in Pennsylvania, only the concrete base and improvements to roads are subject to ad valorem taxation [18]. Other states have adopted exemption periods for property taxes on renewable energy, ranging from a 5-year exemption period in Oklahoma to a 15-year exemption period in New York. The 5-year exemption period in Oklahoma suggests the effects of wind power development upon schools may not follow immediately after a wind farm is installed, but delayed for 5 years.

\section{Methods}

Oklahoma's recent and fast growth of industrial-scale wind power and the historic lower socioeconomic status of the western portion of the state suggest that wind power development may have dramatic impacts on the schools in the region. This research examines how wind power development affects public school districts located in western Oklahoma. The state of Oklahoma has a total of 517 school districts (OEQA, 2016), of which data were collected for 108 , representing approximately $20 \%$ of the state [17]. These districts were selected to represent the western half of the state, with approximately $37 \%$ of the 108 districts with and 63\% without industrial wind turbines as of the end of 2014. Of the study area, 41 districts contained all of the state's wind turbines, while the other districts selected were near districts without wind turbines. See Fig. 1 for a map of wind turbine locations as of 2010 and the study area.

Following from previous where the relationships between presence of wind turbines and socioeconomic characteristics and public school attributes were analyzed at the county level in Texas, relevant variables were collected and analyzed for this research $[15,16]$. These variables include percentage of revenue from local and

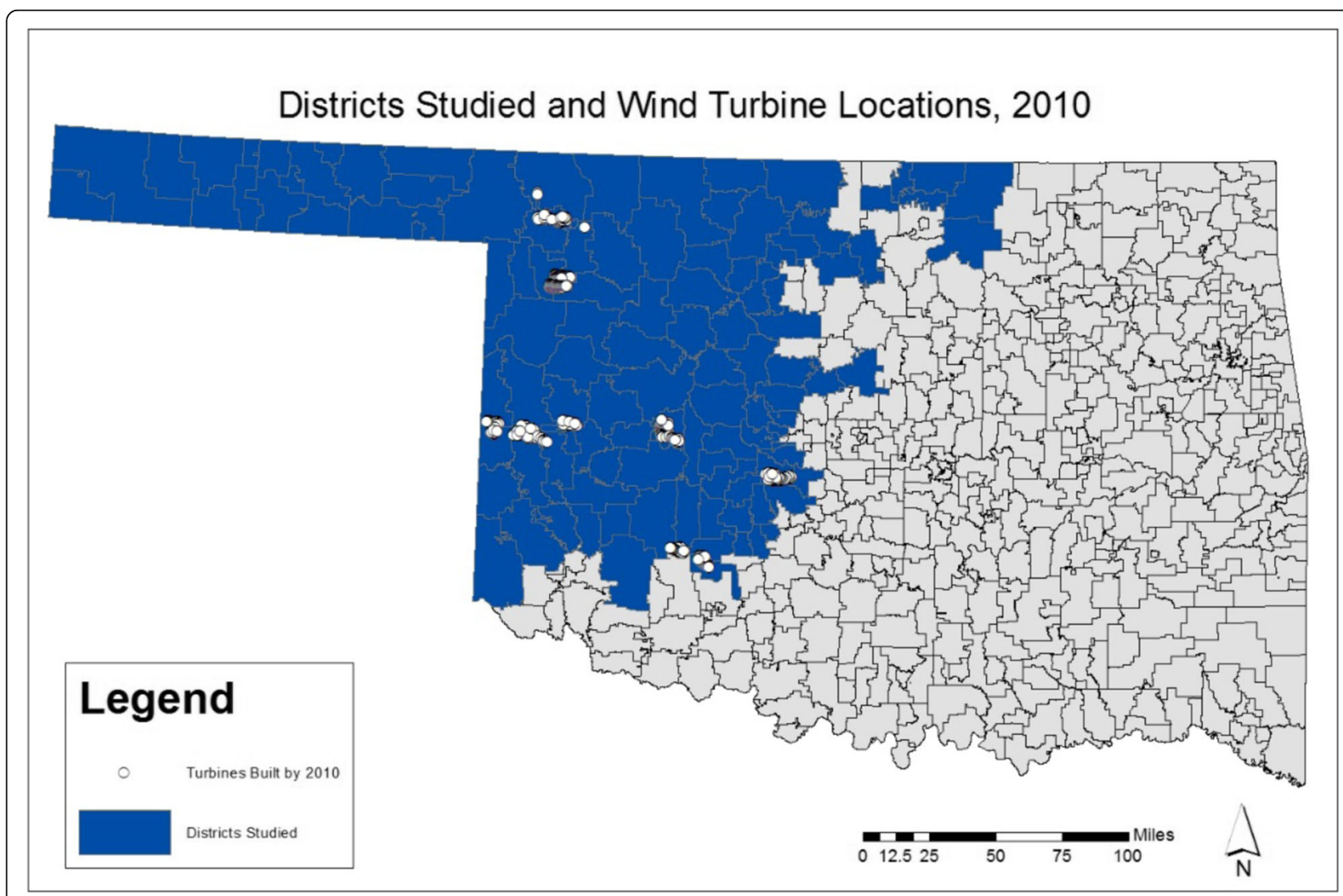

Fig. 1 Map of study area and wind turbine locations 
county sources, student-teacher ratios, and per-student expenditures. Data were collected for these variables at the school district level from the Office of Educational Quality and Accountability for 19 years, beginning in 1997 and ending in 2015. The year 1997 was selected as the start date since that was the first year for which the data were available at the school district level. The data were mapped and analyzed using appropriate descriptive and inferential statistical methods in order to identify spatial patterns related to wind power development and statistically meaningful differences between school districts with wind turbines and surrounding districts with no turbines. In addition, a longitudinal temporal analysis was undertaken for selected locations to further illustrate the impact of the wind farms on the region.

In order to determine differences between school districts with wind turbines and those without turbines, independent-samples $t$ tests, independent-samples Mann-Whitney $U$ tests, and descriptive analyses were used when appropriate. For example, while it may be appropriate to use independent-samples $t$ tests to compare means for skewed data if sample size is greater than 30, Mann-Whitney $U$ tests were also used since initial visual analysis of the data suggests that Gaussian assumptions may be violated in some instances. The percentage change variables were developed and selected so that the relative change would be used to standardize the impact by school district. The use of percentage change, rather than the actual values, is a commonly accepted analytical tool, and is a way to more adequately compare the relative change on the districts. These variables were calculated based on the total percentage change over the entire time period for which data are available (1997-2015).

There is a 5 -year property tax exemption period in the state, so the definition of districts with and without turbines factors this into the analysis. Thus, for example, property values may increase immediately as a result of wind turbines, but the effects such as more revenue available for local services as a result of increased property taxes may not be realized by the community until after the 5-year exemption period ends. The analysis described below takes this into consideration. When examining percentage of revenue from local and county sources, student-teacher ratios, and per-student expenditures, districts were split into two groups--those with turbines in 2010 or before $(n=18)$, and those without turbines in $2010(n=90)$, again, this is to account for the 5-year ad valorem exemptions. Thus, while it may appear that 2010 is an arbitrary start date, this start date is necessary given both the nature of the available data and the state's 5-year exemption law. However, it is possible that there still may be other impacts of the wind farm that might be able to be seen on the school districts before the 5-year period.
For example, local consumption will increase during construction and this may have an impact on the school district. To address this, we have examined our selected variables across the entire time series (1997-2015). Thus, any such patterns will be able to be determined even with the 5 -year exemption period.

In examining the potential relationship between the wind industry and the school districts it is also important to consider how the property tax assessments are determined for the state. The ad valorem taxes are collected as a percent of the worth of the property itself and structures on that property. Thus, for example, the taxes will change based on the relative cost of the turbine in a location, rather than the actual amount of electricity produced by that turbine.

\section{Results and discussions}

\section{Change in local and county revenues}

The first variable that was examined was the percentage of district revenues from local and county sources. Given that the Office of Educational Quality and Accountability has identified that school districts with a greater percentage of revenues from local and county sources are typically more economically well-off than those with lower percentages of revenues from local and county sources, this variable was selected to examine if there are differences in percentage of local and county revenues between districts with wind and with turbines in 2010 or before. As above, appropriate statistical tests (e.g., independent-samples $t$ tests and Mann-Whitney $U$ tests) were used. The results reveal statistically significant differences in percentage change in local and county revenues between districts with and without turbines in 2010 or before. For example, districts with turbines in 2010 or before saw an average increase in local and county revenues of approximately $55.8 \%$, while districts without turbines in 2010 only saw an average increase of approximately $26.1 \%$. Refer to Tables 1 and 2 for the results of the independent-samples $t$ tests, independent-samples and Mann-Whitney $U$ tests. Furthermore, Fig. 2 shows how the distributions of percentage change in local and county revenue differ

Table 1 Results of independent-samples $t$ tests

\begin{tabular}{lllll}
\hline Variable & Year built & $N$ & $\begin{array}{l}\text { Mean \% } \\
\text { change }\end{array}$ & $\begin{array}{l}P \text { value } \\
(\text { sig. at } a=0.05)\end{array}$ \\
\hline $\begin{array}{l}\text { Local and county } \\
\text { revenues }\end{array}$ & Turbines in 2010 & 18 & 59.8 & $<0.001$ \\
$\begin{array}{l}\text { Student-teacher } \\
\text { ratio }\end{array}$ & Turbines in 2010 & 18 & 5.3 & 0.889 \\
Per-student & No turbines in 2010 & 90 & 3.9 & \\
expenditures & Turbines in 2010 & 18 & 90.8 & 0.435 \\
& No turbines in 2010 & 90 & 88.2 & \\
\hline
\end{tabular}


Table 2 Results of independent-samples Mann-Whitney $U$ tests

\begin{tabular}{ll}
\hline Null hypothesis & $\begin{array}{l}P \text { value } \\
\text { (sig. at } a=0.05)\end{array}$ \\
\hline $\begin{array}{l}\text { The distribution of percentage change in local and } \\
\text { county revenue is the same across districts with and } \\
\text { without turbines in } 2010 .\end{array}$ & 0.001 \\
$\begin{array}{l}\text { The distribution of percentage change in } \\
\text { student-teacher ratios is the same across districts } \\
\text { with and without turbines in } 2010 .\end{array}$ & 0.581 \\
$\begin{array}{l}\text { The distribution of percentage change in } \\
\text { per-student expenditures is the same across districts } \\
\text { with and without turbines in 2010. }\end{array}$ & 0.692 \\
\hline
\end{tabular}

between districts with wind turbines in 2010 or before and districts without turbines in 2010. Figure 2 shows the almost $30 \%$ difference in median change and also an over $50 \%$ difference for the upper quartile.

In addition to the statistical analysis, it is also useful to examine the spatial patterns of percentage change in local and county revenue across the study area. Figure 3 shows the percentage change in local and county revenue from 1997 to 2015. Overall, it appears there are several cases where a particularly high percentage change in local and county revenue (greater than 75\%) occurs within districts with turbines. Typically, these are districts with very small enrollments. Compared to the rest of the study area without turbines in 2010, typical percentage change ranged from less than zero to $75 \%$.

As above, it may be worthwhile to examine the temporal patterns in the relationships between the districts with and without turbines. Figure 4 shows a time series of percentage of revenue from local and county sources for the Sharon-Mutual and Lookeba-
Sickles school districts. These districts were selected as they had similar enrollment and percentage local and county revenue as of 1997 with approximately 232 students enrolled in Sharon-Mutual and approximately 234 enrolled in Lookeba-Sickles. Figure 4 shows the percentage of revenue from local and county sources for Sharon-Mutual begins to spike in 2009, when turbines were built within the district, while Lookeba-Sickles does not have turbines and does not see a spike in percentage of revenue from local and county sources.

\section{Change in student-teacher ratio}

Given the statistically significant differences in percentage change in local and county revenues between districts with turbines and those without turbines, it was hypothesized that districts that were more financially well-off (i.e., greater percentage change in percentage of revenue from local and county sources) would have lower student-teacher ratios. Additionally, school districts with wind turbines were expected to have significantly lower student-teacher ratios following from the analysis of Kahn (2013) whereby it was concluded that counties in Texas with wind turbines had lower student-teacher ratios than those that did not have turbines. However, for this study, the independentsamples $t$ tests and independent-samples Mann-Whitney $U$ tests showed no statistically significant differences in percentage change in student-teacher ratio from 1997 to 2015 between districts with turbines in 2010 or before and districts without turbines. For example, districts with wind turbines in 2010 had a mean percentage increase in student-teacher ratio of approximately 5.3\%.

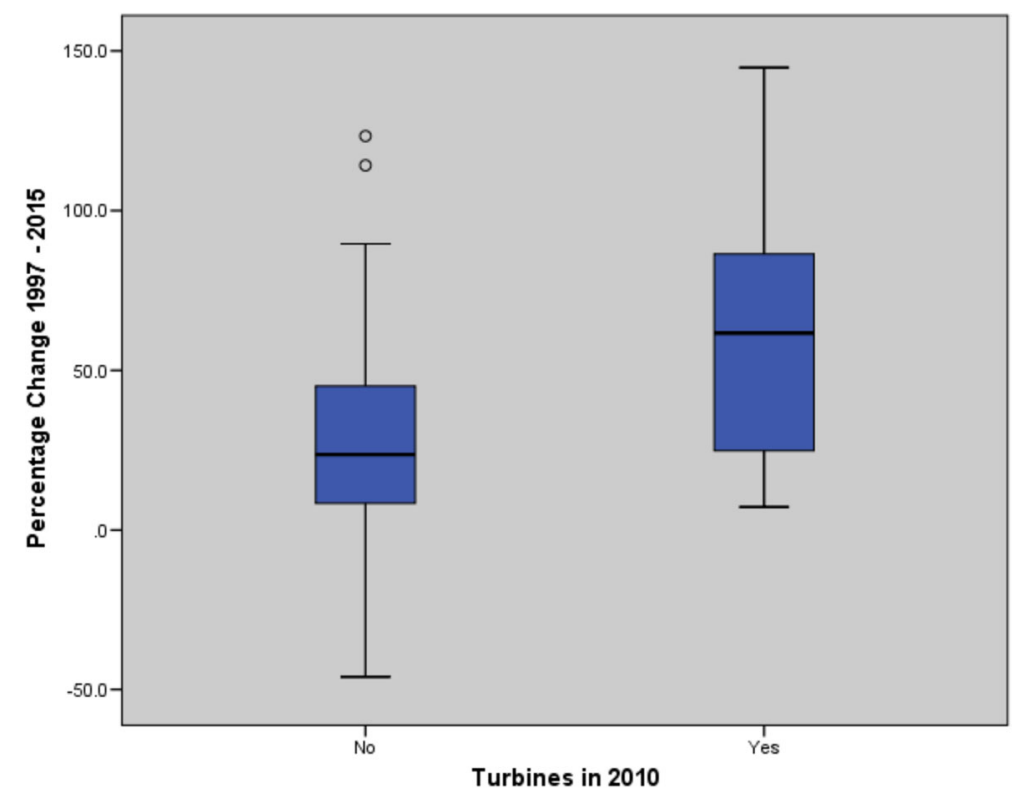

Fig. 2 Percentage change in local and county revenue between districts with and without turbines 


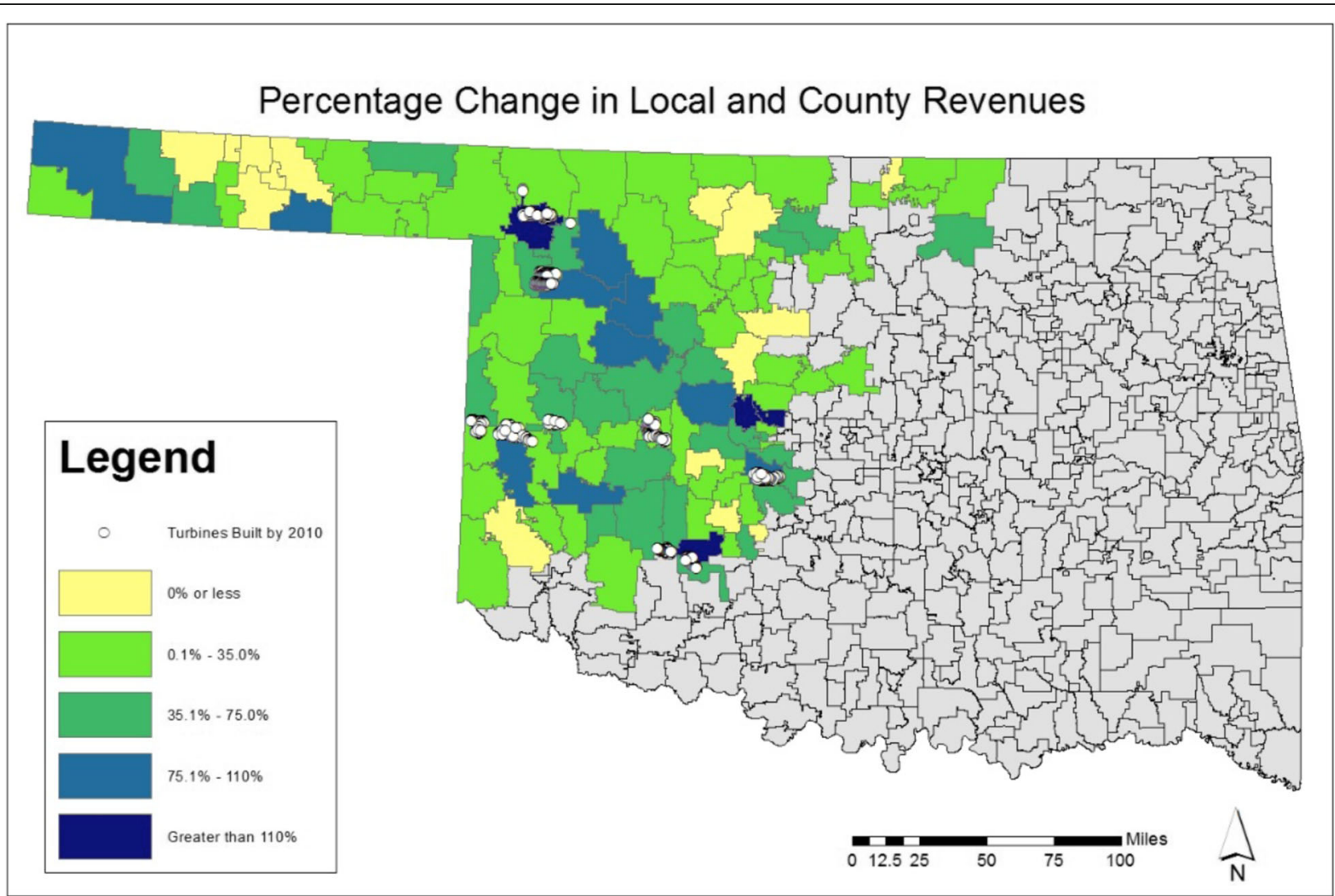

Fig. 3 Map of percentage change in local and county revenue

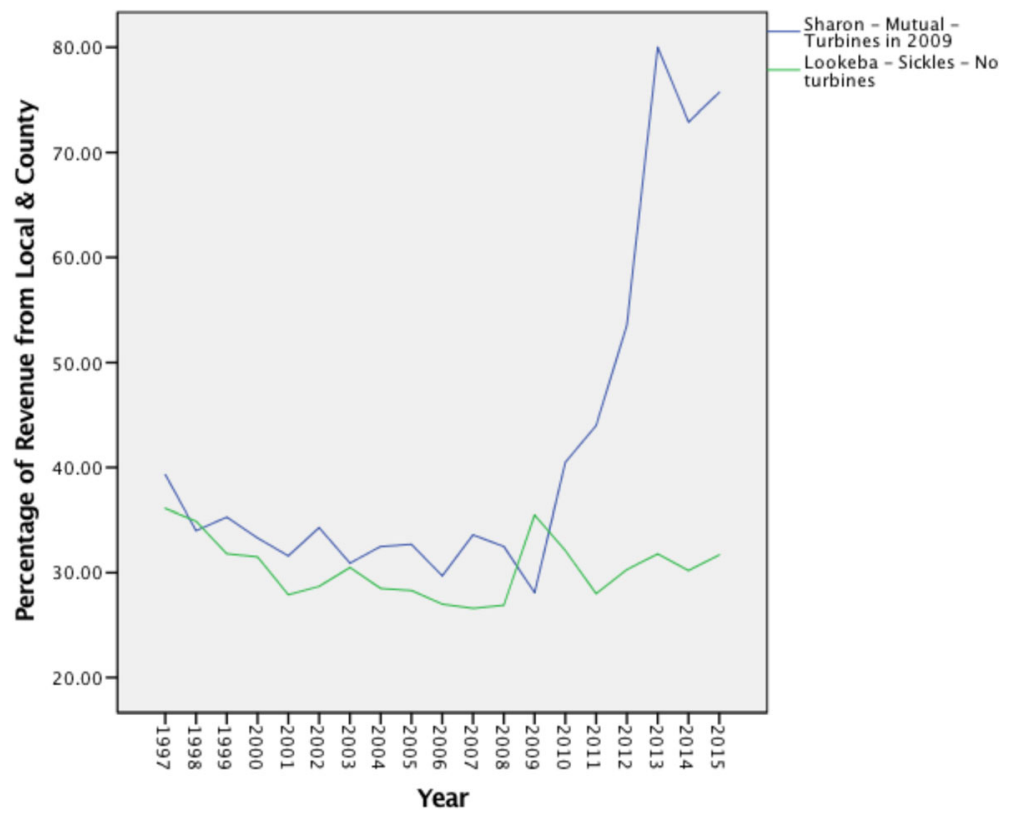

Fig. 4 Time series graph of local and county revenue for Sharon-Mutual and Lookeba-Sickles districts 


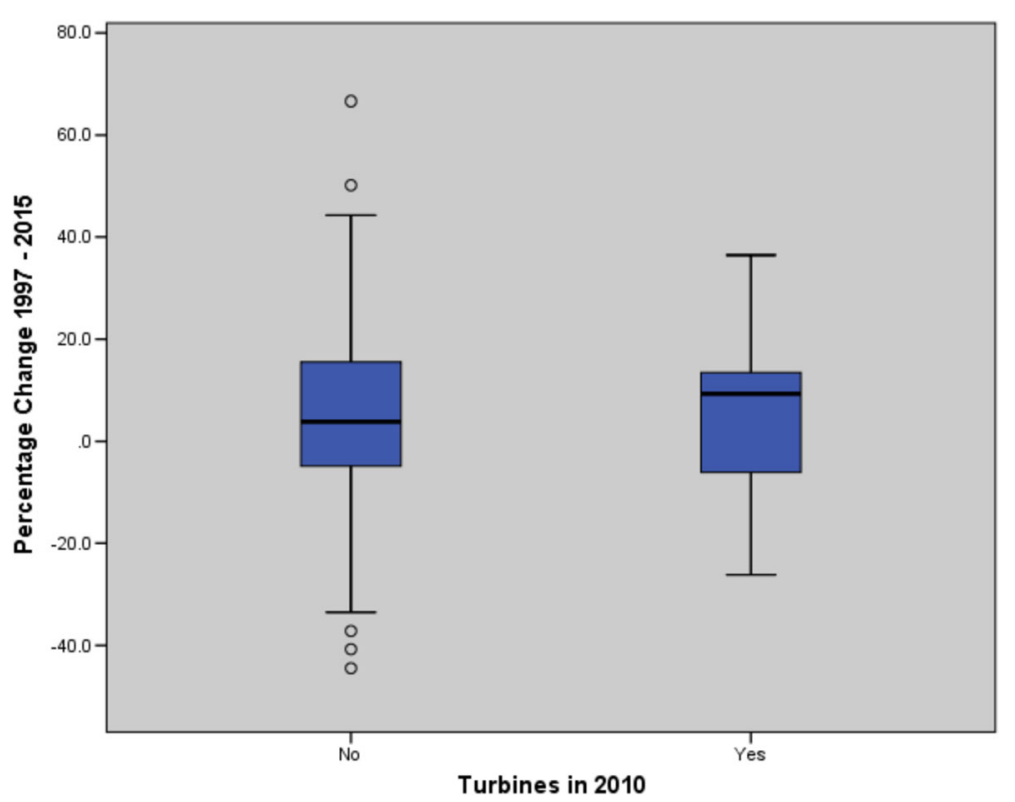

Fig. 5 Change in median local and county revenue for all districts

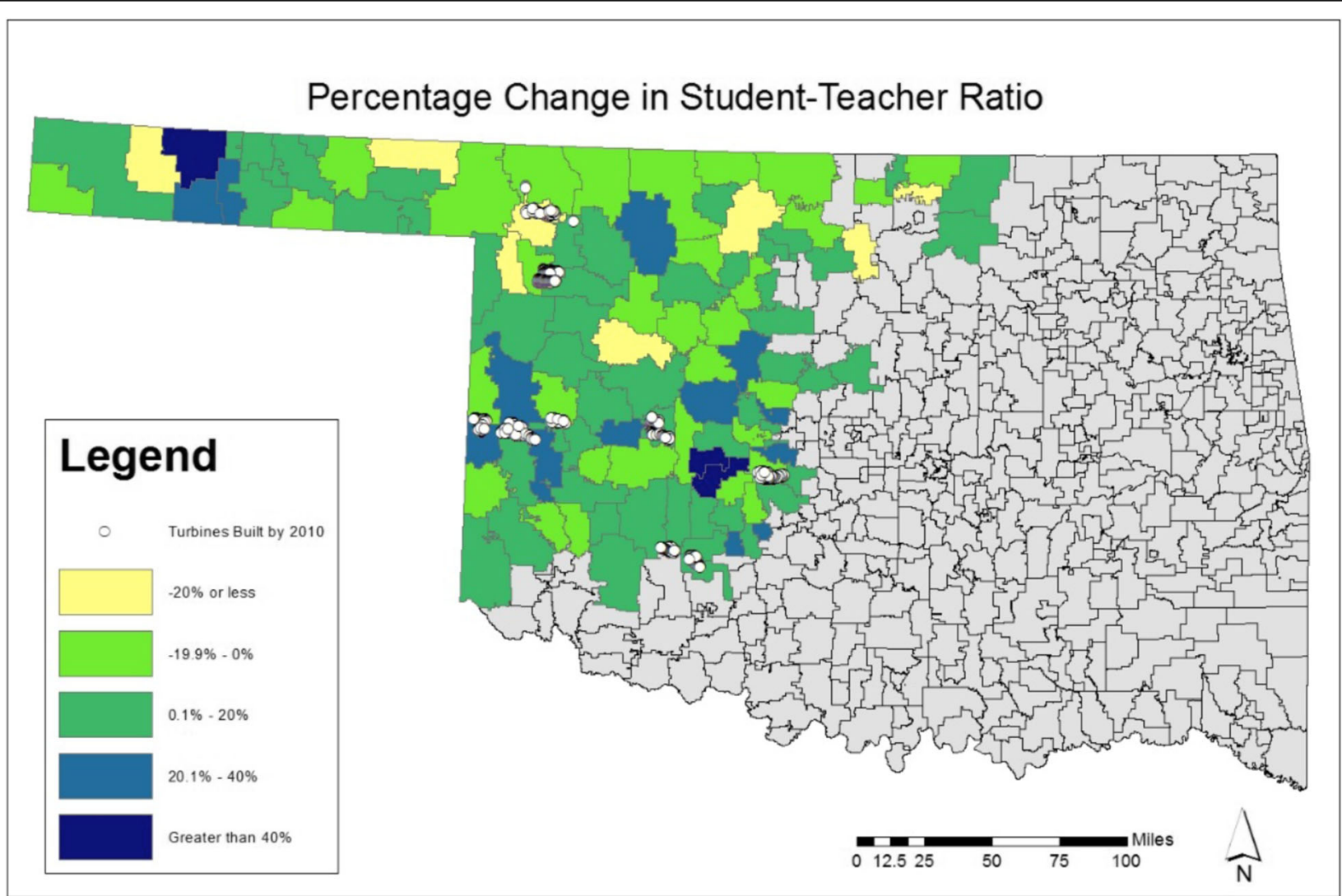

Fig. 6 Percentage change in student-teacher Ratio between districts with and without turbines 
Districts without turbines in 2010, however, actually saw a smaller mean percentage increase of approximately $3.9 \%$. Figure 5 shows the distributions for percentage change in student-teacher ratio between districts with turbines in 2010 or before and districts without turbines in 2010. See Tables 1 and 2 for the results of the independent-samples $t$ tests and independent-samples Mann-Whitney $U$ tests.

As with the local and county revenue, the spatial patterns of percentage change in student-teacher ratio across the study area were examined to gain a more complete understanding of how percentage change in student-teacher ratio may differ across districts with and without turbines in 2010. Figure 6 shows the percentage change in student-teacher ratio from 1997 to 2015. Overall, there are a few cases where a particularly noticeable percentage decrease ( $0 \%$ or less) in studentteacher ratio occurs within districts with turbines, but this is not typically the case. Most districts within the study area experienced an increase in student-teacher ratio between 0.1 and $20 \%$.

The results of the statistical and spatial analysis were expected to show significant differences between districts with wind turbines in 2010 or before and districts without turbines in 2010, but no such pattern was identified. However, by examining some isolated examples of total change in student-teacher ratio over time, a clearer picture of how this change may differ across districts with turbines and those without may develop. Figure 7 shows the change in student-teacher ratio for the Fort Supply and Burlington school districts. These districts were selected because they had similar enrollment and student-teacher ratios in 1997 with each district having a total enrollment of 165 students. Fort Supply, however, sees a sharp decrease in student-teacher ratio beginning in 2009. Ultimately, the Fort Supply and Burlington school districts have a greater difference in studentteacher ratio in 2015 than in 1997, with Fort Supply having the lower student-teacher ratio of the two districts. These figures illustrate that for selected districts, the installation of industrial wind turbines has resulted in large and significant decreases in the student-teacher ratios.

\section{Change in per-student expenditures}

The final variable examined for this research is that of per-student expenditures. Given the 5-year tax exemption period, it was originally expected that school districts with turbines installed in 2010 or before might have significantly higher per-student expenditures than districts without turbines in 2010. However, it can be seen from Fig. 8 that the distributions of percentage change in per-student expenditure are fairly similar between districts with turbines in 2010 and districts without turbines. The independent-samples $t$ test and independent-samples Mann-Whitney $U$ test both showed no statistically significant differences in percentage change in per-student expenditures between districts with turbines in 2010 and districts without turbines in 2010. See Tables 1 and 2 for the results of the independent-samples $t$ tests, and independent-samples Mann-Whitney $U$ tests.

In order to visualize how districts with turbines in 2010 or before might differ from those without turbines in terms of percentage change in per-student expenditures, percentage change in per-student expenditures,

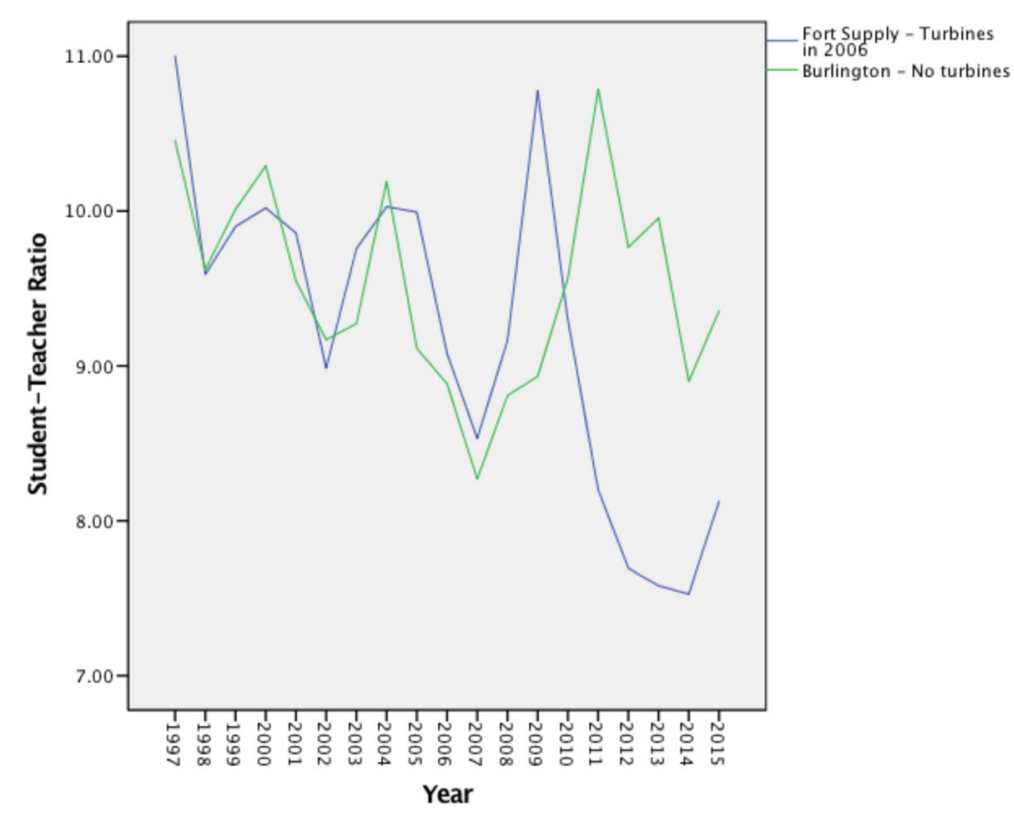

Fig. 7 Map of percentage change in student-teacher ratio 


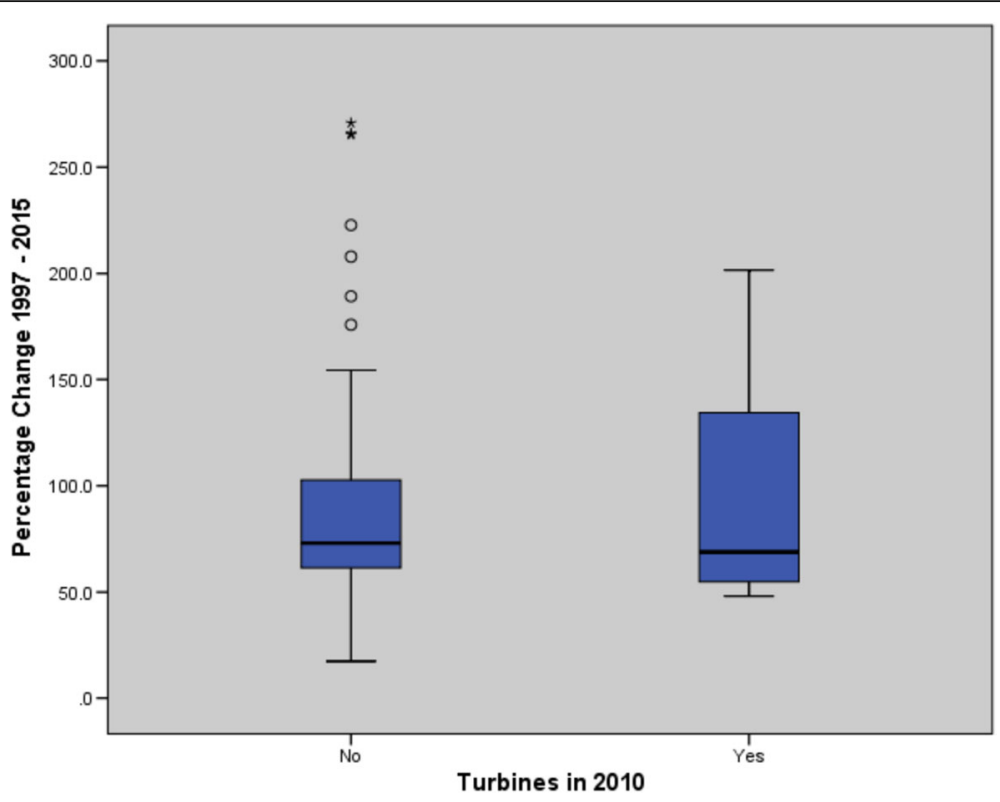

Fig. 8 Time series graph of student-teacher ratio for Burlington and Fort Supply districts

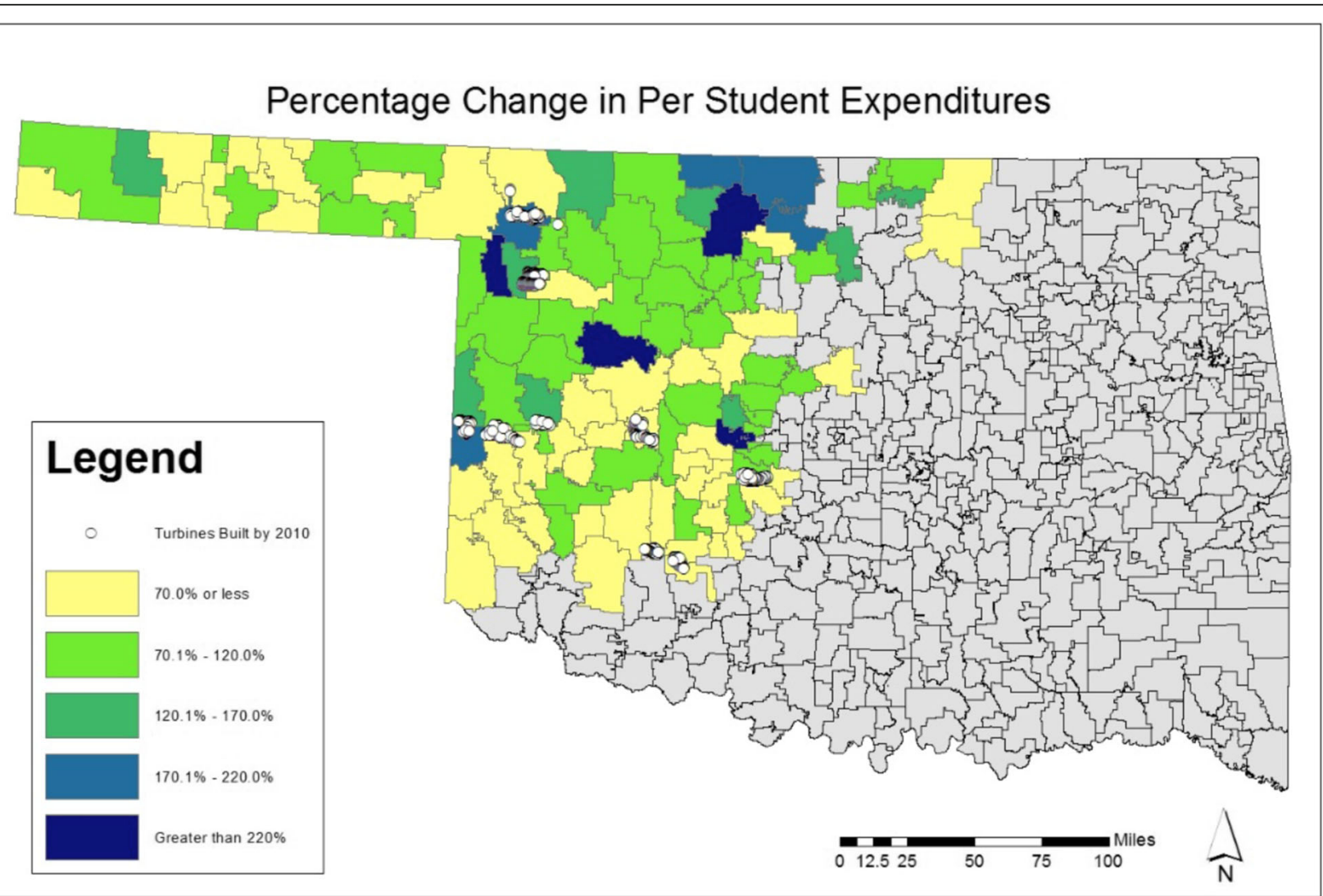

Fig. 9 Time series graph of student-teacher ratio for Buffalo and Ringwood districts 


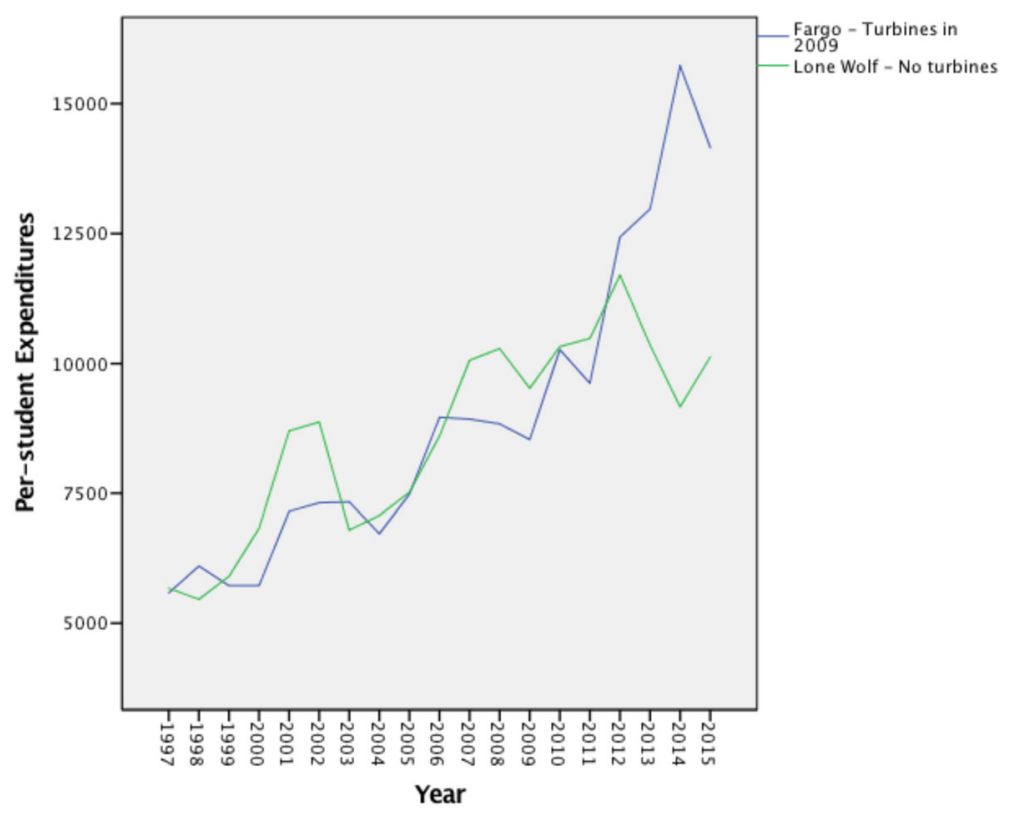

Fig. 10 Percentage change in per-student expenditures between districts with and without turbines

and wind turbine locations were mapped. Figure 9 shows a map of percentage change between 1997 and 2015 in per-student expenditures and wind turbine locations as of 2010. There are several cases where a particularly high percentage change in per-student expenditures (greater than 170\%) occurs within districts with turbines; however, typical increases in per-student expenditures were less.
As with the analysis above, time series graphs of selected districts show how per-student expenditures have changed over time between districts with turbines in 2010 and those without turbines in 2010. A time series graph of the Fargo (209 students) and Lone Wolf (213 students) districts shows an interesting pattern (see Fig. 10). The Fargo and Lone Wolf districts had similar enrollment and per-student expenditures as of 1997, but Fargo school

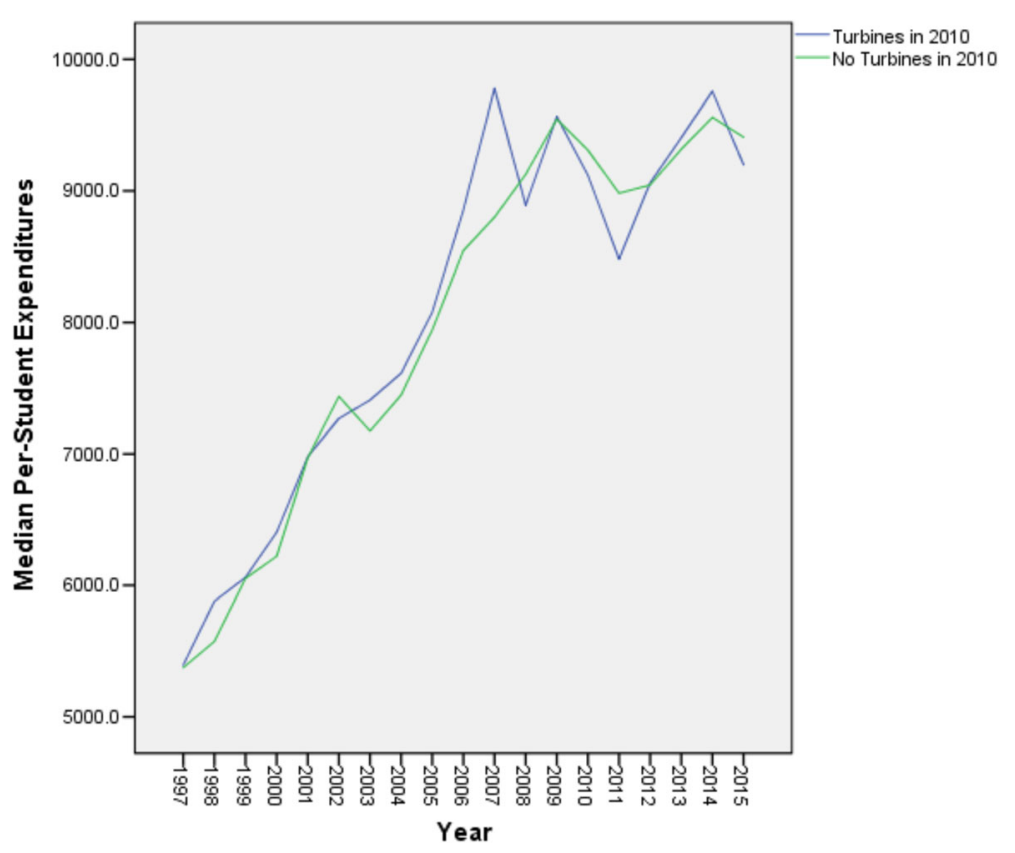

Fig. 11 Map of percentage change in per-student expenditures 
district's per-student expenditures begin to increase rapidly starting in 2009, when turbines were first built within the district. Ultimately, the two districts have a marked difference in per-student expenditures by 2015 .

While it can be seen from isolated examples that perstudent expenditures can differ substantially between school districts with turbines in 2010 and those without turbines in 2010, examining the change in median perstudent expenditures between districts with and without turbines reveals the median per-student expenditure is fairly similar each year for the two groups. In fact, districts with and without turbines in 2010 had very similar median per-student expenditures as of 1997, but districts with turbines in 2010 actually had a lower median per-student expenditure by 2015 (see Fig. 11). It was originally expected that districts with turbines would have higher per-student expenditures, perhaps as a result of increases in property taxes. However, the small difference in median per-student expenditures and the statistically not significant independent-samples $t$ test and Mann-Whitney $U$ tests suggest this is not the case. This is perhaps due to the school funding structure in Oklahoma whereby districts that are able to raise a greater percentage of revenue from local and county sources do not receive a large percentage of funding from the state, as these state funds will be allocated to districts that cannot raise revenue from local and county sources [17]. Another explanation is that median values smooth out the impacts for those districts with smaller revenues.
Thus far, this analysis has examined percentage change in local and county revenue, student-teacher ratio, and per-student expenditures separately based on if districts had turbines as or 2010 or did not. However, it is interesting to examine if there is a relationship between number of turbines within a district and its characteristics. Though statistical analysis cannot be done due to the small sample size of districts with turbines, a descriptive analysis shows some interesting patterns in Fig. 12. Figure 12 shows that districts with the most turbines had noticeably lower student-teacher ratios. Furthermore, percentage in revenue from local and county sources was noticeably higher for the third and fourth quartiles. There also appears to be a trend of higher perstudent expenditures within the districts with more turbines excluding the third quartile.

A number of the results from the statistical tests matched previous studies in other locations, and some results were unexpected. Considering the effects of industrial-scale wind development upon property values, it was expected that school districts with industrial-scale wind turbines might experience a greater percentage increase in local and county revenues. It was expected that districts with wind turbines and subsequent increases in property value and tax base would experience a greater percentage change in revenue from local and county sources. This relationship was observed whereby the means and distributions of percentage change in local and county revenue were significantly different between districts with wind turbines and those without wind turbines.

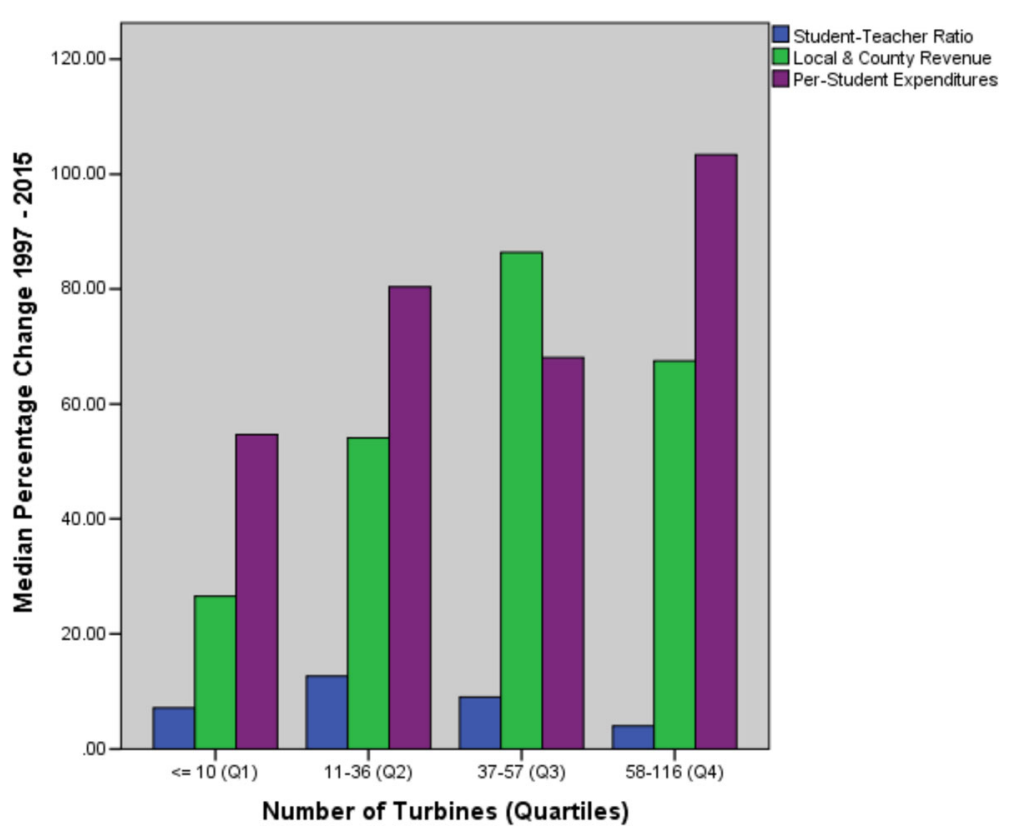

Fig. 12 Time series graph of per-student expenditures for Fargo and Lone Wolf districts 
Though there were statistically significant differences in percentage change in local and county revenue, there were no statistically significant differences in the means and distributions of percentage change in the overall studentteacher ratio between school districts with wind turbines and those without turbines. It was originally expected that school districts with wind turbines might have lower student-teacher ratios considering these districts might have more funds to hire teachers due to the increased property tax base. The examination of the individual cases shows that for selected districts, this pattern is found to be true, and the difference is tremendous, but that overall, the pattern is not as significant due to the number of confounding variables especially for the larger districts.

The final variable analyzed for this research was percentage change in per-student expenditures. There were no significant differences in the means or distributions of percentage change in per-student expenditures between school districts with turbines and those without turbines. The public school funding structure in Oklahoma is such that districts that are able to raise more revenue from local and county sources do not receive as much funding from the state.

Overall, the results of this study show that the addition of wind turbines changes the nature of the revenue stream for school districts in western Oklahoma. For example, the increase in property values and subsequent higher tax base enables school districts with turbines to be more self-sufficient in terms of greater percentages of public school funding originating from local and county sources rather than state or federal sources. Though districts with wind turbines saw greater percentage change in local and county revenues available to public schools, how exactly this influenced characteristics of the schools within the districts such as student-teacher ratios and per-student expenditures was not as clear, although the significance does seem to be more pronounced for selected districts like Fort Supply. However, recall in Oklahoma, the system ensures perstudent expenditures across socioeconomically different school districts remains more equal than it might otherwise be if state funds were not allocated to districts without the ability to raise revenue from local and county sources, so one possible implication is that the funds from the industrial wind turbine allows the state flexibility in distributing the money across the state-so the financial gain is pronounced and significant, just not seen in the with/without analysis.

\section{Conclusions}

The purpose of this research was to conduct statistical and spatial analysis in order to examine differences in western Oklahoma school districts that have industrial- scale wind turbines and those that do not. In order to analyze these differences, data were collected for percentage of revenue from local and county sources, student-teacher ratios, and per-student expenditures for 108 school districts in western Oklahoma over 19 years, from 1997 to 2105.

Although statistically significant differences were not found for each of the variables analyzed, the temporal analysis of selected school districts shows the pronounced impacts of wind power development. There are of course other aspects related to the relative impact of industrial wind turbines on the real estate and tax structure of locations with wind farms. For example, hedonic pricing analysis could be used to examine the relative price structure of properties near and far from the wind turbines within different school districts. Apart from job creation and increases in local economic activity from wind power development, the significant differences in local and county revenues highlight the importance of the wind industry for local communities and perhaps can contribute to decreased susceptibility to changes in public school funding from state and federal sources.

\section{Funding}

Not applicable.

\section{Availability of data and materials}

All data and materials used in this manuscript are housed at the University of Oklahoma and the Oklahoma Wind Power Initiative and are available upon request.

\section{Authors' contributions}

Ms. BC completed the literature review, data analysis, and mapping and assisted with the writing and interpretation of the manuscript. Dr. JSG developed the methods and provided input on the analytical techniques and assisted with the writing and interpretation. Both authors read and approved the final manuscript.

Ethics approval and consent to participate

Not applicable.

Consent for publication

Not applicable.

Competing interests

The authors declare that they have no competing interest.

\section{Publisher's Note}

Springer Nature remains neutral with regard to jurisdictional claims in published maps and institutional affiliations.

Author details

'Oklahoma Alliance for Geographic Education, 100 E. Boyd St, Suite 684, Norman, OK 73019, USA. ²Department of Geography and Environmental Sustainability, University of Oklahoma, 100 E. Boyd St, Suite 510, Norman, OK 73019, USA. 
Received: 3 July 2017 Accepted: 4 October 2017

Published online: 13 November 2017

\section{References}

1. Greene J, Geisken M (2013) Socioeconomic impacts of wind farm development: a case study of Weatherford, Oklahoma. Energy, Sustainability, and Society. doi: 10.1186/2192-0567-3-2

2. American Wind Energy Association (2017). U.S. Wind Energy State Facts. Retrieved from http://awea.files.cms-plus.com/FileDownloads/pdfs/ Oklahoma.pdf. Accessed 10 May 2017.

3. United States Department of Energy (2015) Wind vision: a new era for wind power in the United States

4. Brown JP, Pender J, Wiser R, Lantz E, Hoen B (2012) Ex post analysis of economic impacts from wind power development in U.S. counties. Energy Economics, 34(6):1743-1754

5. Slattery MC, Lantz E, Johnson BL (2011) State and local economic impacts from wind energy projects: Texas case study. Energy Policy. 39:7930-7940

6. Grover S (2002) The economic impacts of a proposed wind power plant in Kittitas County, Washington State, USA. Wind Engineering. 26(5):315-328

7. Leistritz FL Coon RC (2009) Socioeconomic impacts of developing wind energy in the great plains. Great Plains Research, 19:3-12

8. Okkonen $\mathrm{L}$, Lehtonen $\mathrm{O}$ (2016) Socio-economic impacts of community wind power projects in Northern Scotland. Renew Energy 85:826-833

9. Ejdemo T, Soderholm P (2015) Wind power, regional development and benefit-sharing: the case of Northern Sweden. Renew Sust Energ Rev: 476-485

10. United States Government Accountability Office (2004) Wind power's contribution to electric power generation and impact on farms and rural communities

11. Lantz E, Tegen S (2009) Economic development impacts of community wind projects: a review and empirical evaluation. National Renewable Energy Laboratory. https://www.nrel.gov/docs/fy09osti/45555.pdf.

12. Governors' Wind Energy Coalition (2013) Renewable electricity standards: state success stories

13. Pedden M (2006) Analysis: economic impacts of wind applications in rural communities. National Renewable Energy Laboratory. https://www.nrel.gov/ docs/fy06osti/39099.pdf.

14. Reategui S, Hendrickson S (2011) Economic development impact of 1,000 MW of wind energy in Texas. National Renewable Energy Laboratory. https://www.nrel.gov/docs/fy110sti/50400.pdf.

15. Kahn ME (2013) Local non-market quality of life dynamics in new wind farms communities. Energy Policy 59:800-807

16. De Silva DG, McComb RP, Schiller AR (2016) What blows in with the wind? South Econ J 82(3):826-858

17. Office of Educational Quality and Accountability (2016) Retrieved from https://www.ok.gov/oega/School_\&_District_Profiles_Reports/State_ Reports.html. Accessed 14 Oct 2016.

18. DeLacy PB (2014) Renewables, tax credits, and ad valorem taxes: are policies aligned? Real Estate Issues 39:50-58

\section{Submit your manuscript to a SpringerOpen ${ }^{\circ}$ journal and benefit from:}

- Convenient online submission

- Rigorous peer review

- Open access: articles freely available online

- High visibility within the field

- Retaining the copyright to your article 